ISSN 1980-5918

Fisioter. Mov., Curitiba, v. 29, n. 4, p. 669-676, Oct./Dec. 2016

Licenciado sob uma Licença Creative Commons DOI: http://dx.doi.org/10.1590/1980-5918.029.004.A002

\title{
Analysis of lower limb force in foot work exercise of Pilates
}

\author{
Análise da força de membros inferiores no \\ exercício foot work do método Pilates
}

\author{
Carolina Neis Machado, Ana Paula Moratelli Prado, Elisa Dell'Antonio, Deise Ferreira de Oliveira, \\ Suzana Matheus Pereira, Helio Roesler*
}

Universidade do Estado de Santa Catarina (UDESC), Florianópolis, SC, Brazil

\begin{abstract}
Introduction: Pilates is a physical exercise method that uses the resistance of springs to modulate the overload from exercises. Objective: To characterize the force versus time curve of the foot work exercise; verify and compare the force applied by the same limb during the foot work exercise against the resistance of two types of springs with different elastic constants, and verify and compare the asymmetry of force applied by right and left lower limbs during the foot work exercise against the resistance of the same type of spring. Methods: Twenty healthy adult individuals familiarized with Pilates were evaluated. Two extensometric force plates adapted to the Reformer apparatus were used. Each participant performed 10 repetitions of the exercise against the resistance of two pairs of springs with different elastic constants. Descriptive and inferential statistics were used with significance levels of $\mathrm{p}<0.05$. Results: The exercise's standard curve showed that the peak force is reached in the point of maximum hip and knee extension during the execution of the exercise. There were differences between force production by the same limb for different springs
\end{abstract}

*CNM: MS, e-mail: krolinanm@gmail.com APMP: MS, e-mail: anamoratelli2@gmail.com EDA: MS, e-mail: elisadellantonio@yahoo.com.br DFO: BS, e-mail: deisefo@hotmail.com SMP: PhD, e-mail: suzana.pereira@udesc.br HR: PhD, e-mail: helio.roesler@udesc.br 
( $<<0.001)$ and between left and right limb when spring with lower elastic constant was used $(p=0.006)$. No differences were found between right and left limb when spring with higher elastic constant was used $(p=0.108)$. Conclusion: The knowledge of the force versus time curve and the quantification of unilateral force are important elements in the evaluation and prescription of exercises.

Keywords: Pilates. Instrumentation. Motor Activity.

\section{Resumo}

Introdução: O Pilates é um método de exercício físico que utiliza a resistência de molas para modular a sobrecarga dos exercícios. Objetivo: Caracterizar a curva de força versus tempo do exercício foot work; verificar e comparar a força aplicada pelo mesmo membro durante o exercício foot work contra a resistência de dois tipos de molas com constantes elásticas diferentes; e verificar e comparar a assimetria de força aplicada pelos membros inferiores direito e esquerdo durante o exercício foot work contra a resistência do mesmo tipo de mola. Métodos: Foram avaliados 20 indivíduos adultos saudáveis e familiarizados com o Pilates. Utilizou-se duas plataformas de força extensométricas adaptadas ao aparelho Reformer. Cada participante realizou 10 repetições do exercício contra a resistência de dois pares de molas com constantes elásticas diferentes. Utilizou-se estatística descritiva e inferencial, com nível de significância de p <0,05. Resultados: A curva padrão do exercício demonstra que o pico de força é alcançado no ponto máximo de extensão do quadril e joelho durante a execução do exercício. Houve diferenças entre a produção de força do mesmo membro para diferentes molas $(p<0,001)$ e entre os membros direito e esquerdo para uma mola de menor constante elástica $(p=0,006)$. Não foram encontradas diferenças entre os membros direito e esquerdo para uma mola de maior constante elástica $(p=0,108)$. Conclusão: $O$ conhecimento da curva de força versus tempo e a quantificação da força unilateral são importantes elementos na avaliação e prescrição de exercícios.

Palavras-chave: Pilates. Instrumentação. Atividade Motora.

\section{Introduction}

The popularity of Pilates has stimulated the development of studies investigating its effectiveness, evaluating the effects of training programs on different parameters such as muscle strength and muscle endurance $(1,2)$, flexibility $(3,4)$, decreased pain $(5$, $6)$, joint function restoration $(5,7)$ among others. Given the positive results, the method has been increasingly indicated and used in training and orthopedic rehabilitation programs, with emphasis on the rehabilitation of lower limbs $(7,8)$.

Rehabilitation of lower limbs in Pilates is given by the variety of open and closed kinetic chain exercises, with possible restrictions on the range of motion, and gradual increase in load (9). In this sense, the foot work exercise stands out, which is characterized as an closed kinetic chain exercise, similar to leg press in relation to the motor gesture (flexion-extension of hips and knee), but differs in relation to the position of the individual and external load $(10,11,12)$. In Pilates, exercise is performed on the Reformer apparatus, with the individual positioned in supine position with feet supported on a bar; this horizontal position reduces the action of gravity (13), being commonly used when the injured joint is not able to support the entire body weight (14). External overload occurs by the use of springs, through which the change in length (applied force), the type of material (elasticity modulus), and the cross section dictate the strength magnitude and the value of the stored potential energy (15). In this exercise, the spring is stretched during the knee extension movement, generating a gradual increase in resistance, and progressively decreases during the movement return in knee flexion.

Some studies to date have analyzed this exercise from the biomechanical point of view, describing muscle activation and force moments $(16,17,18)$, considering the results bilaterally, without a specific analysis for each lower limb. In the study by Vilardi (17), the effect of different elastic loads on cinematic strategies and electromyography activation during foot work exercise was investigated. The results indicate that the increment of elastic load causes increased electrical activation of muscles involved and reduced ankle peak velocity. In the study by Cantergi et al. (18), it was observed that individuals 
can perform the exercise using different coordinative strategies due to the change in direction of the resultant force applied by the foot of the individual against the reformer support bar. However, regardless of strategy used, knee extensor muscles were the main contributors for the exercise.

As the external load in Pilates is modulated according to the variation of the elastic constant of springs and number of springs, professionals use subjective criteria (perceived exertion) to control exercise overload $(13,19)$. Both in training and rehabilitation processes, exercise load should always be consistent with the subject's needs, especially in rehabilitation processes in which the use of inappropriate loads may delay recovery (insufficient loads) or even worsen the injury (excess load) (20). In this sense, is of crucial importance to quantify the loads applied during the exercise and know the force applied at each instant of the movement.

Considering that the foot work exercise is commonly used bilaterally in rehabilitation programs and physical training $(14,21)$, an important aspect to be investigated is the unilateral measurement of the force applied by the subject against different elastic loads. Such evaluation will provide basic information to understand the force symmetry between limbs and load progression in Pilates. Comparisons between limbs are used in orthopedic assessments and balance tests in order to diagnose functional instabilities, make therapeutic decisions, evaluate the results and determine whether the patient is able to start the gait training and/or sports activities (22). Additionally, the assessment of the symmetry of force between limbs is used as a criterion for determining the level of experience and the training evolution (23). The measurement of unilateral external forces may be used as a tool indicative of overload in the musculoskeletal system, muscle imbalances and support load modulation in exercises and exercise progression (24).

Given the above, the aims of this study were 1) to characterize the force versus time curve of the foot work exercise; 2) to check and compare the force applied by the same limb during foot work exercise against the resistance of two types of springs with different elastic constants; and 3) to check and compare the asymmetry of the force applied by left and right lower limbs during foot work exercise against the resistance of the same type of spring.

\section{Methods}

\section{Subjects}

The study included 20 healthy adults $(26.4 \pm 2.8$ years, $63.2 \pm 11.0 \mathrm{~kg}$ and $1.66 \pm 0.06 \mathrm{~m}$ ) of both genders (15 women and 5 men) who met the following inclusion criteria: absence of musculoskeletal impairment and be familiar with the Pilates method (minimum of 8 classes). Individuals with length difference between right and left lower limbs above $0.02 \mathrm{~m}$ were excluded. All participants had the right limb as dominant.

\section{Procedures}

The aims and procedures of the study were initially explained to participants, who signed the Informed Consent Form. The study was approved by the Ethics Committee on Research Involving Human Beings of the University of the State of Santa Catarina - UDESC (109.446/2012). Subsequently, personal identification data, lower limb dominance and anthropometric measurements were obtained. Participants were assessed in the Reformer apparatus, where they familiarized themselves with the different loads (springs), being instructed to keep slight abduction and external rotation of hips, and support the hindfoot on the support bar in order to avoid the contribution of the extensor muscles of ankles during leg extension.

Each participant performed 10 repetitions of the exercise for each of the two pairs of springs (red springs with elastic constant of $491 \mathrm{~N} / \mathrm{m}$ blue springs with elastic constant of $353 \mathrm{~N} / \mathrm{m}$ ), with 2 minutes of rest between sets. The order of performance with different springs was randomized.

\section{Instrumentation}

To perform the analysis of each of the lower limbs, two extensometric force plates adapted to the Reformer apparatus were used, as described by Machado, Dell' Antonio and Roesler (25), with acquisition rate of $500 \mathrm{~Hz}$, connected to the ADS 2002 IP system (Lynx Tecnologia Eletrônica LTDA). Due to the original angle of the Reformer apparatus support bar, where the plates were fixed, it was necessary to carry out the exchange of coordinate systems to obtain the horizontal force values (it has higher contribution in foot work, because the exercise is performed in that direction). Figure 1 shows the equation used for exchanging the coordinate system. 


\section{FH $=$ Fxh + Fyh \\ $\mathrm{FH}=(\mathrm{Fx} \times \operatorname{sen} \alpha)+(\mathrm{Fy} \times \cos \alpha)$}

Figure 1 - Equations used for the exchange of the coordinate system.

\section{Data processing}

After acquisition, data were stored and exported through AqDAnalysis 7.0.14 software (Lynx Tecnologia Eletrônica LTDA) to be treated in specific routine of the SAD32 software (26). An initial cut in the first two and last two replicates of each participant was performed, considering the six central curves as the best representation of the movement (Figure 2).

\section{Statistical analysis}

Descriptive (mean and standard deviation) and inferential statistics were used. The paired test t was used to compare the symmetry of force production of right and left limbs and also to compare the force produced by the same limb in both situations using springs. In all tests, the SPSS 20.0 software for Windows was used and the significance level for all tests was $95 \%(p=0.05)$.

\section{Results}

The force versus time curves of the 20 participants in this study showed similar characteristics. Figure 2 shows the force versus time curve of participants during the execution of the foot work exercise. It was observed that the force production varies according to the movement phase, and the peak force is reached at the point of maximum hip and knee extension during exercise.

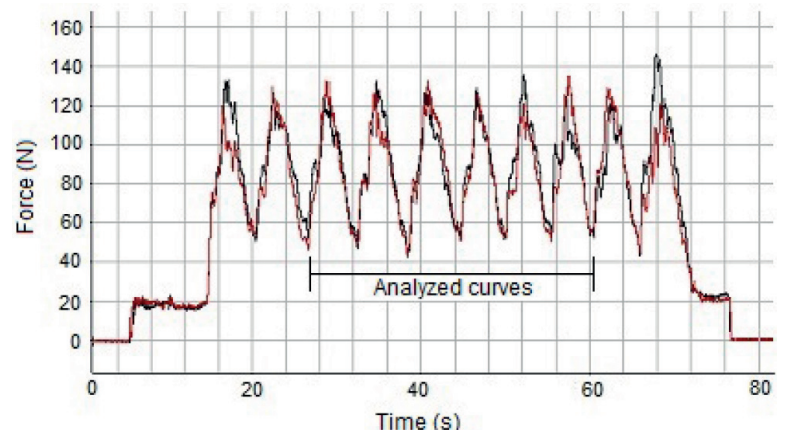

Figure 2 - Horizontal force (N) versus time (s) curve of the right (curve in black) and left lower limbs (curve in red) against the resistance of two blue springs.
Comparing symmetry between limbs for the same spring condition (Figure 3), it was observed that for the pair of red springs, no differences between the peak horizontal force production between right and left limbs ( $p=0.108)$. However, for the pair of blue springs, significant differences were found $(p=0.006)$ between peak horizontal force production between right and left limbs. When comparing the effect of blue and red springs on horizontal peak force production of the same limb (Figure 3), the results indicate that the horizontal peak force production for the red spring was significantly higher than for the blue spring $(\mathrm{p}<0.001)$.

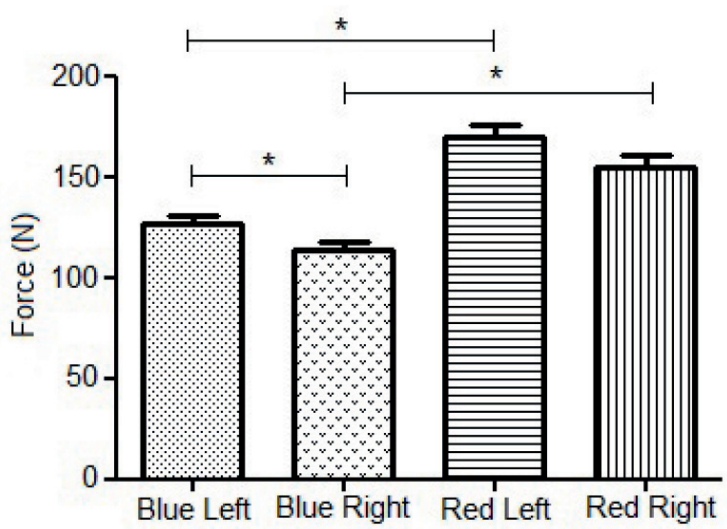

Figure 3 - Horizontal peak force production (N) of each limb against the resistance of different springs, where blue is the performance of exercise against the resistance of a pair of blue springs and red is the performance of exercise against the resistance of a pair of red springs; Left is the use of the left leg; and Right is the use of the right leg. *Indicates significant difference $p<0.05$.

\section{Discussion}

Among the findings of this study, the characterization of the force versus time curve of the foot work exercise stands out (Figure 1). Such characterization is of fundamental importance for exercise prescription, since professionals need to know which phases of the movement produce more or less force $(13,19)$. Importantly, the force production during the foot work exercise, due to increased resistance imposed by springs when they are stretched, increases with a linear characteristic during the concentric phase of 
the exercise and the peak force production coincides with the end of this phase. In contrast, during the eccentric phase, due to the return of spring to the starting position, there is a reduction of force production levels until the start of a new run.

Along with the characterization of the force versus time curve, it was necessary to quantify the application of these forces, and this measurement is the main mechanical overload indicator imposed on the locomotive apparatus of participants. In this study, quantifying forces during foot work exercise allowed two different analyses. The comparison of the peak force of the same limb against the resistance of two pairs of springs with different elastic constants showed that, as expected, the peak force was greater for the springs of greater elastic constant for both right and left lower limbs (Figure 2). In a similar study, Self et al. (13) used load cells to measure the reaction force of the lower limbs of dancers during flexion-extension movement of hips and knees, in external rotation and hip abduction performed in the Reformer apparatus, which resembles the demi-plié ballet movement. The force generated during exercise performed against the resistance of four springs was significantly higher (men, $369 \mathrm{~N}$; women, $298 \mathrm{~N}$ ), approximately $60 \%$ of the body weight, than against the resistance of only two springs (men, $200 \mathrm{~N}$ women $164 \mathrm{~N}$ ), approximately $30 \%$ of the body weight. These results are explained by the fact that springs with greater elastic constant offers greater resistance to movement and thereby more force is needed to move them.

Furthermore, the use of two independent force platforms (one for each foot) allowed comparing the symmetry of force production between right and left lower limbs against the resistance of the same pair of springs (Figure 2). It is crucial to emphasize that, unlike the variation of the peak force production against springs with different elastic constants in which the professional knows in what situation the resistance to movement is higher or lower during bilateral exercise, the professional cannot judge subjectively the symmetry of force production between limbs.

In the present study, it was observed that, although the dominance of the entire sample was the right lower limb, for the pair of springs with a smallest elastic constant, the left limb showed higher average peak force compared to the right limb. Similar results were found in previous studies $(27,28)$. James et al. (27) instrumented a leg press apparatus with two force platforms analyzing the force symmetry of the lower limbs in physically active subjects against three different loads (50\%, $100 \%$ and $150 \%$ of body weight) and verified that force was significantly higher in the non-dominant leg (4 - 12\%). Mognoni et al. (28) reported higher knee extensors peak torque values of the non-dominant limb compared to the dominant limb in young soccer players. This result was attributed to the actions support of and balance of body weight carried out by the non-dominant limb when the contralateral limb performs the kick movement. However, our study analyzed healthy subjects experienced at Pilates, which allows speculating that differences can be explained by the fact that loads were so light that did not require higher force production from the dominant limb, as for the pair of springs of higher elastic constant, no differences in peak force production between left and right limbs were found.

Other authors $(23,29)$ also found no differences in the comparison between dominant and non-dominant limbs in the evaluation of force in trained and sedentary individuals. Pinto et al. (30) suggested that there is a tendency to lateral similarity of homologous limbs in subjects familiar with strength training, especially bilaterally. However, literature is still scarce about this behavior in Pilates exercises, although its knowledge is of paramount importance to determine the evolution of the individual and guide his progression in the method.

Asymmetry of lower limbs can lead to biomechanical abnormalities of posture and movement, negatively affecting both limbs either by excess demand for one of the limbs, increasing the burden on its joint, or by the weakness in the contralateral limb, decreasing its capacity to absorb large forces associated with daily and sports activities $(24,31)$. In addition, the return to symmetry of limbs is a common goal in rehabilitation processes (32) and symmetry in force production is often emphasized in strength training programs (27). Thus, the importance of assessing unilateral force for the diagnosis of possible imbalances, prescription and monitoring of rehabilitation and training programs is highlighted.

\section{Conclusion}

The Reformer apparatus instrumentation has important applications for professional practice and enables the description of the force versus time curve morphology, comparing the peak force production 
under different resistance conditions and analyzing symmetry between limbs. For subjects evaluated in this study, there was increased peak force for springs of greater elastic constant when compared to springs of lower elastic constant. For springs of lower elastic constant, significant difference of peak force between lower right and left limbs was observed. There were no asymmetries for springs of higher elastic constant. These results demonstrate the clinical potential of this type of evaluation.

For future studies, it is suggested the use of other measurement methods such as electromyography and kinemetry combined with dynamometric evaluation for the biomechanical understanding of the foot work exercise. The use of greater variety of loads and precise control of the movement speed execution are also suggested.

\section{References}

1. Sekendiz B, Altun O, Korkusuz F, Akin S. Effects of Pilates exercise on trunk strength, endurance and flexibility in sedentary adult females. J Bodyw Mov Ther. 2007;11(4):318-26.

2. Ferreira CB, Aidar FJ, Novaes GS, Vianna JM, Carneiro AL, Menezes LS. O método Pilates sobre a resistência muscular localizada em mulheres adultas. Motricidade. 2007;3(4):76-81.

3. Segal NA, Hein J, Basford JR. The effects of Pilates training on flexibility and body composition: an observational study. Archives of physical medicine and rehabilitation. Arch Phys Med Rehabil. 2004;85(12):1977-81.

4. Guimarães ACA, Azevedo SF, Simas JPN, Machado Z, Jonck VTF. The effect of Pilates method on elderly flexibility. Fisioter Mov. 2014;27(2):181-8.

5. Rydeard R, Leger A, Smith D. Pilates-based therapeutic exercise: effect on subjects with nonspecific chronic low back pain and functional disability: a randomized controlled trial. J Orthop Sports Phys Ther. 2006;36(7):472-84

6. Miyamoto GC, Costa LO, Galvanin T, Cabral CM. The efficacy of the addition of the Pilates method over a minimal intervention in the treatment of chronic nonspecific low back pain : a study protocol of a randomized controlled trial. J Chiropr Med. 2011;10(4):248-54.
7. Levine B, Kaplanek B, Scafura D, Jaffe WL. Rehabilitation after total hip and knee arthroplasty: a new regimen using Pilates training. Bull NYU Hosp Jt Dis. 2007;65(2):120-5.

8. Levine B, Kaplanek, B, Jaffe WL. Pilates training for use in rehabilitation after total hip and knee arthroplasty: a preliminary report. Clin Orthop Relat Res. 2009;467(6):1468-75.

9. Bryan M, Hawson S. The benefits of pilates exercise in orthopaedic rahebilitation. Tech Orthop. 2003;18(1):126-9.

10. Cantergi D. Avaliação das forças musculares envolvidas no exercício de extensão do quadril e joelho do método Pilates [master's thesis]. Porto Alegre (Brazil): Universidade Federal do Rio Grande do Sul; 2011. Portuguese.

11. Hay D, Souza VA, Fukashiro S. Human bilateral deficit during a dynamic multi-joint leg press movement. Hum Mov Sci. 2006;25(2):181-91.

12. Azegami M, Yanagihashi R, Miyoshi K, Akahame K, Ohira M, Sadoyama T. Effects of multi-joint angle changes on EMG activity and force of lower extremity muscles during maximum isometric leg press exercises. J Phys Ther Sci. 2007;19(1):65-72.

13. Self BP, Bagley AM, Triplett TL, Paulos LE. Functional biomechanical analysis of the pilates-based Reformer during demi-plie movements. J Appl Biomech. 1996;12(3):326-37.

14. Shedden M, Kravitz L. Pilates exercise a researchbased review. J Dance Med Sci. 2006;10(3):111-6.

15. Hughes CJ, Hurd K, Jones A, Sprigle S. Resistance properties of Thera-Band tubing during shoulder abduction exercise. J Orthop Sports Phys Ther. 1999;29(7):413-20.

16. Santos AB. Análise comparativa de variáveis Biomecânicas e da percepção de esforço do exercício leg work do Pilates realizado na Chair e no Reformer [master's thesis]. Porto Alegre (Brazil): Universidade Federal do Rio Grande do Sul; 2010. Portuguese.

17. Vilardi PR. Ánalise biomecânica e de controle motor do exercício de flexão e extensão do joelho realizado no reformer com diferentes níveis de resistência segundo o método Pilates [master's thesis]. São Paulo: Uninove; 2010. Portuguese. 
18. Cantergi D, Loss JF, Jinha A, Brodt GA, Herzog W. Muscle estrategies for leg extension on a "Reformer" apparatus. J Electromyogr Kinesiol. 2015;25(2):260-4.

19. Melo MO, Gomes LE, Silva YO, Santos AB, Loss JF. Resultant muscular force and resistance torque assessment during hip extension exercise in pilates and its implications on prescription and progression. Rev Bras Fisioter. 2011;15(1):23-30.

20. Dale RB. Principles of rehabilitation. In: James Andrews, Gary Harrelson, Kevin Wilk. Physical rehabilitation of the injured athlete. 4th edition. Amsterdam: Elsevier; 2012: 41-66.

21. Musculino JE, Cipriani S. Pilates and the "powerhouse" - I. J Bodyw Mov Ther. 2004;8(1):15-24.

22. Alonso AC, Brech GC, Bourquin AM, Greve JMD. A influência da dominância dos membros inferiores no equilíbrio postural. Sao Paulo Med J. 2011;129(6):410-3.

23. McCurdy K, Langford G. Comparison of unilateral squat strength between the dominant and nondominant leg in men and women. J Sports Sci Med. 2005;4(2):153-9.

24. Almeida GPL, Carneiro KKA, Morais HCR, Oliveira JBB. Effects of unilateral dominance of the lower limbs on flexibility and isokinetic performance in healthy females. Fisioter Mov. 2012;25(3):551-9.

25. Machado CN, Dell'Antonio E, Roesler H. Instrumentação e calibração do aparelho reformer do método pilates para análises biomecânicas. Corpus et Scientia. 2013;9(1):101-14

26. Silva LM, Zaro MA. Sistema de aquisição de dados SAD 2 Versão (3.0): Manual de operação. Porto Alegre: UFRGS-DEMEC; 1997.

27. James DA, Simjanovic M, Leadbetter R, Wearing S. Design and test of a custom instrumented leg press for injury and recovery intervention. Procedia Engineering. 2014;72:38-43.

28. Mognoni P, Narici MV, Sirtori MD, Lorenzelli F. Isokinetic torques and kicking maximal ball velocity in young soccer players. J Sports Med Phys Fitness. 1994;34(4):357-61.
29. Tookuni KS, Bolliger Neto R, Pereira CAM, Souza DR, Greve JMDA, D’Agosto AA. Comparative analysis of postural control in individuals with and without lesions on the anterior cruciate ligament of the knee. Acta Ortop Bras. 2005;13(3):115-9.

30. Pinto RS, Botton CE, Kuckartz BT, Lima CS, Moraes AC, Bottaro M. Avaliação do déficit bilateral em contrações isométricas dos extensores de joelhos. Rev Bras Cineantropom Desempenho Hum. 2012;4(2):202-11.

31. Maupas E, Paysant J, Datie AM, Martinet N, André JM. Functional asymmetries of the lower limbs. A comparison between clinical assessment of laterality, isokinetic evaluation and electrogoniometric monitoring of knees during walking. Gait Posture. 2002;16(3):304-12.

32. Barber-Westin SD, Noyes FR. Objective criteria for return to athletics after anterior cruciate ligament reconstruction and subsequent reinjury rates: a systematic review. Phys Sportsmed. 2011;39(3):100-10.

Received in 10/31/2014 Recebido em 31/10/2014

Approved in 11/11/2015 Aprovado em 11/11/2015 
